ISSN: 1641-4713; e-ISSN: 2081-1160

DOI: https://doi.org/10.36551/2081-1160.2020.26.307-326

\title{
Spirituality and ecology within the phenomenological realm of secularity ${ }^{1}$
}

\author{
Espiritualidade e ecologia dentro do domínio fenomenológico \\ da secularidade
}

Luz Gonçalves Brito

Núcleo de Estudos da Religião

Universidade Federal do Rio Grande do Sul (UFRGS), Brazil

ORCID iD: https://orcid.org/0000-0002-1639-3721

E-mail: luzgonbrito@gmail.com

Recepción: 30.04 .2020

Aprobación: 24.09 .2020

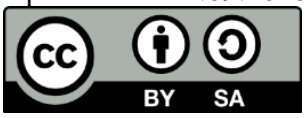

\begin{abstract}
This article is based on the theoretical analysis of empirical material gathered by means of socio-anthropological research. The aim is to present some reflections on the relations between ecology, spirituality and secularity as three intricate aspects of modern thought. First, the methodological contribution of the article is questioning the aprioristic association between New Age and spirituality. Later, there is an analysis of ecological thought and spirituality, addressing the broader context of secularity understood as an immanent frame of experience. Finally, the article proposes some possible directions for the study of spirituality and ecology without the methodological pitfalls disentangled throughout the text.
\end{abstract}

Keywords: spirituality, ecological thought, secularity, ecological epistemologies, New Age.

\footnotetext{
${ }^{1}$ Some ideas of this article were discussed during the Conference of the International Society for Sociology of Religion, in Barcelona, 2019. An incipient bibliographic review has been expanded in this article and can be found in my previous essay, published in 2018: O sagrado no quadro imanente da modernidade: Algumas linhas para uma antropologia da espiritualidade. In M. Tadvald (Ed.), Religião e Sociedade: estudos, trajetórias e desafios (pp. 39-76). Casa Verde.
} 
Resumen: Este artículo está basado en el análisis teórico del material empírico elaborado en el marco de una investigación antropológica. El objetivo es presentar algunas reflexiones sobre las relaciones entre ecología, espiritualidad y secularidad, todo ello atendiendo a tres aspectos intrincados del pensamiento moderno. En primer lugar, desde la metodología, cuestionar la asociación apriorística entre espiritualidad y nueva era. En segundo lugar, analizar el pensamiento ecológico y la espiritualidad, bajo un contexto amplio de secularidad, entendido como marco inmanente de la experiencia. Por último, el artículo propone algunas orientaciones posibles para el estudio de la espiritualidad y la ecología sin los escollos metodológicos que se han ido desenmarañando a lo largo del texto.

Palabras-clave: espiritualidad, pensamiento ecológico, secularidad, epistemologías ecológicas, New Age.

\section{INTRODUCTION}

The relations between environmentalism and religion have been reported by social sciences for many years. The contemporary debate regarding this issue dates back to at least three decades ago where different analysis axes were explored. For instance: living in millenarian ecological communities as a global response to the constantly ailing capitalist system (Léger \& Hervieu, 1983); the reciprocal influence between earth-based spiritualities and environmental movements (Taylor, 2001); ecological and holistic ideas presented by self-declared spiritual individuals (Crespo, 1994); the impact of deep ecology upon New Age thought (Hanegraaff, 1996); the rise of ecological consciousness among many religious movements (Giner \& Tábara, 1999); countercultural and alternative communities whose discourses are subtly or openly ecological (Amaral, 2000), and so on.

Although the theme has never lost its relevance, after the broad cultural diffusion and large political usages of the questions of climate and nature, other research has been dedicated to the comprehension of the phenomena. Different questions then rose, such as the importance of ecological discourses within the Church, especially after the encyclical Laudato Si released by Pope Francis (Santos, 2017); the role of religious actors, institutionalized or not, in environmental debates (Koehrsen, 2018); the presence and absence of feminist agendas in spiritual ecology (Becci \& Grandjean, 2018); or even the ecological conceptualizations in intentional communities which collide epistemological and political Euro-American assumptions (Caravita, 2012; Cykman, 2018). On the other hand, the dimension of religion and spirituality - the latter being our analytical concept here, which will be defined precisely in the next section - seems hitherto rarely addressed in studies regarding sustainability issues, whose approaches are usually "technology-focused" (Koehrsen, 2018, p. 50). Within an entire volume dedica- 
ted to environmental issues on land and water rights, released by this journal, Revista del Cesla (n. 23), the word religion - and also spirituality - was scarcely mentioned, and when it was mentioned it was neither a central subject nor a category of analysis. Given the apparently secondary space of spirituality amidst other scientific articles on ecological issues, emphasizing the theme is a relevant task.

It is important to delineate my contribution considering the main point of departure for this study: which are the basic assumptions that relate ecology and spirituality? Ecology is a systemic science, often holistic in its approaches, whose concepts regard totalities, the ecosystems. We will not be interested here in its methods or techniques of research. The important point is that the attention to the 'pattern that connects' living organisms (Bateson, 1986) is not restricted to ecology as an academic discipline, but is also a notion disseminated throughout other sciences and even outside academia, flourishing among environmentalist movements.

That basic assumption, drawn by Bateson, is spread out in many EuroAmerican societies. Ecological thought can be discerned where the notion of the interrelation between living organisms is present. It seems useful to dig out and find the ecological thought under the surface of discourses shared among collectives we are studying with. Analogously, within this article, spirituality will be understood as the sense of interrelation and the search for connection with every being in the world. The double methodological nexus and the empirical ground from which it was taken will be explained in the following sections. Nevertheless, I want to anticipate that ecological thought and spirituality will be understood as two different forms of perception and conception regarding the connections between beings in the world.

The main aim of this article is to articulate the conceptualization of spirituality and the issue of secularity, understanding spirituality as an autonomous category in relation to the notions of religion and New Age. The socio-anthropological analysis will show that an accurate understanding of spirituality may address its intertwining with secularity. After presenting the methodological context from which the reflection arises, the article draws a necessary socio-historical overview of the debate on secularity. Then, the following parts are anthropologically dedicated to the relations between ecology and spirituality as two realms of a secular frame. Besides some analytical findings based on the fieldwork in the ecovillage Arca Verde, such as the notion of an immanent sacred of nature, the article finishes with some possible methodological directions for further investigations on the emergent question of ecology and spirituality. 


\section{METHODOLOGICAL THREAD: NEW AgE, SPIRITUALITY AND BEYOND}

Some lines about the methodological context in which the following reflections are inserted. In the search for delimitation of the subject of my current research on spirituality and ecology, an extensive bibliography concerning the New Age movement was consulted, including many articles and books on New Age where spirituality was mentioned. A theoretical association between the notions of New Age and spirituality was found (Hanegraaff, 1999; Heelas, 2006). Both notions appear in texts whose assumptions are the psychologization of religion in the secular context. The idea that New Age implies a kind of relative individual autonomy of practicing a religion of the self or, more specifically a spirituality of the self, often without institutional mediations, have an important place in many discussions of New Age (Amaral, 2000; Bender \& McRoberts, 2012; Camurça, 2003; Carozzi, 1999; Champion, 1993; Magnani, 2000; Oliveira, 2014; Torre, 2011).

Actually, it is not a surprise that spirituality has been associated with countercultural discourses, which present some similarities to what is understood as New Age. According to Hanegraaff, "the term 'New Age' has entered the standard vocabulary in discussions about ideas and practices regarded as alternative vis à vis dominant cultural trends, especially if these ideas and practices seem to be concerned with "spirituality"' (1996, p. 1). Methodologically, spirituality is a keyword that has been used to localize New Age phenomena. In a sense, what has been called "the New Age style to deal with the sacred" (Amaral, 1999) highly focused on inward practices of the person and development of human potential - has also been understood as a kind of religiosity whose practitioners do not go to churches.

The phenomena of 'New Age spirituality' is usually attributed to the contemporary sociological process that led to the disjunction of religion and state, but also as a result of the increasing individualism as value, from which rose the cult of the autonomous subject, their body and well-being (Luiz, 2013). The supreme value at stake for new agers would be then the "sacralization of individual autonomy" (Carozzi, 1999) in the context of post-modern psychologization, reflexivity and globalization (D'Andrea, 2000). The crucial issue was the individualistic ethics and to a certain extent the decline of religious traditions with concomitant global cultural exchanges, which elicited "the development of the autonomous self and the associated subjective turn of modernity" (Heelas, 2006, p. 58). That religious autonomy seems to have given to individuals the freedom to create their own sys- 
tems of belief with deterritorialized ideas and practices, as spiritual bricoleurs (Camurça, 2003). There is also a remarkable phenomenon of cultural appropriation of several Eastern ideas and practices by Euro-American societies, a process through which religious elements are translated in terms of psychotherapeutic techniques often described as 'spiritual' (Barnes, 1998). Either way, the ascertainment of the close link between the notion of New Age and the notion of spirituality is also noticeable in the apparent swap of its visible features: both are understood as a form of 'strictly personal' connection with the sacred (Torre, 2011).

The previous analysis of this complex phenomenon practically drew New Age with shades of an apparent ubiquity. Within the Brazilian field of social sciences, since the systematizations of Amaral (1999, 2000) and Magnani (1999, 2000), the concept of New Age was taken as an umbrella term. It tries to grasp several discourses - such as self-development, ecologies, or even improvement of attention skills - expressed by many people in different places - from esoteric temples to workshops, alternative communities and capitalist corporations. Amaral (2000) suggested that New Age would be better comprehended as an adjective used to characterize different phenomena, instead of a noun establishing a substantive or fixed fact. Nevertheless, that important suggestion was not sufficient to prevent the exhaustion of the term. After the boom of research regarding the theme at the turn of the century, there was a quantitative decrease in the number of texts (Guerriero et al., 2016). According to Toniol:

the quantity of phenomena characterized as New Age and the insistent trend of social scientists of religion to ascribe the category in their ethnographies, however, allow us to suspect that we are before a situation where the continuous usage of certain analytical language imprisoned the multiplicity of observed realities in the fiction created to describe them. (2015a, p. 20)

The reduction in the quantity of research is paradoxically related to the propagation of "New Age ethos" (Guerriero et al., 2016) in various domains of social life, but also to the apparent theoretical ubiquity that impede us to situate the phenomena by means of the category.

Although it is impossible to deny the importance of this broad concept that has been valuable to encompass a large range of empirical data, it seems also undeniable that the concept has been overstretched (Toniol, 2015b). The methodological problem begins when the concept is applied indistinctly to many different situations, because, if the phenomenon is present everywhere, one could fairly say that it is nowhere. Furthermore, Toniol (2015b) also mentions the movement of "renewalization" (novaerização, in Portuguese), concerning the appropriation 
of New Age features by secular and religious institutions, as an example of this methodological issue. On the other side, there is also another recent movement, at the same time empirical and theoretical, called "leaving the New Age". In the field of alternative therapeutic practitioners, for instance, the term New Age has been gradually abandoned by the same people that once claimed it, while key practices and concepts (like energy and the energetic practices) were being validated and integrated as secular techniques in health systems (Toniol, 2015a).

If we do not want our analysis to be captive to the methodological category that once was useful, it will be wise to parenthesize the term New Age instead of taking for granted its theoretical association with spirituality. Following the critique that Toniol presented, my aim was to untangle spirituality and New Age, revealing a fertile tension based on the refusal of an a priori association between them. My proposal is not to disregard the connection between New Age and spirituality, but rather to recognize the connection and to suspend it, in order to breathe fresh air and renew their potentialities without subordinating or overlaying one another.

The task of understanding the analytical category of spirituality requires an exploration of empirical studies of its manifestations. This article subscribes to the premise that the notion of spirituality cannot be detached from political and historical discursive disputes (Giumbelli \& Toniol, 2017). That understanding leads us to adjust the attention to different forms through which the notion is discursively used, enabling us to catch the phenomena more precisely. Besides the first theoretical displacement carried out above, there is indeed another necessary methodological movement to be made, if we want to draw an accurate understanding of the multiplicity of spirituality.

Looking to the contemporary problematization of the specificity of the notion of religion is elucidating. This debate has shown that the notion of religion could not be simply applied uncritically to non-western contexts without bringing with it many assumptions, which obnubilate the comprehension of religious phenomena (Asad, 1993). The problem is extended to the study of spirituality because spirituality has been often understood in relation to religion (Camurça, 2016; Carvalho, 1992; Hanegraaf, 1996) ${ }^{2}$. The crucial point is the necessity of

\footnotetext{
${ }^{2}$ One of the pioneer studies regarding spirituality in Brazil can be found on Carvalho (1992), according to which spirituality is "the way certain individual internalizes, develops, always idiosyncratically, the particular path or model of union (or re-union, to recover the origin of the term religion) proposed by their religion. Hence, spirituality already implies the dimension of a cultivated subjectivity, of an experience that transcends the norm or formal expectation of a community" (p. 4).
} 
thinking on spirituality beyond an essentialist or trans-historical notion, which has always been the mainstream analytical assumption, since the World Parliament of Religions, in Chicago, 1983. According to Veer (2009), the idea of "world religions" based on written traditions was coined during that occasion, when religious representatives of many countries gathered. The assumption of "some essential Truth shining in all existing religions" (p. 1105) was foundational to the emerging studies of religion.

Hence, the same problems regarding universal concepts of religion are also embedded in the notion of spirituality:

Social scientists frequently juxtapose spirituality to religion and identify the former by way of what it lacks in comparison to the latter. In particular, spirituality would appear to lack institutions, authority structures, community, and even history - all of which are considered integral to religion, such as it is widely understood today. (Bender \& McRoberts, 2012, p. 2)

Methodologically, the Euro-American model of religion has been often used to localize spirituality. And, also, the assumption of universal or essential notion of religion had a prevailing influence on further analysis.

Moreover, spirituality was then loosely opposed to materiality and the body, alongside the contrast between the religious and the secular (Veer, 2009, p. 1097). The fact that the notion of spirituality has usually been defined in such a vague manner fostered connections between several discursive traditions. Indeed, the analytical dispersion of spirituality in scholarly research corresponds to its dispersion in the social world. That process is not a problem in itself, since the study of spirituality needs to address the diversity and heterogeneity of conceptions concerning the phenomenon. Viotti's suggestion is valuable, according to which "spirituality is a category that does not have a defined meaning, but it does not have infinite possible meanings" (2018, p. 236).

In a sense, it seems that sociological, historical and anthropological studies could find a reasonable exit within this methodological maze. Once the focus is dislocated to culturally situated notions of spirituality, it is possible to leave behind a single aprioristic analytical concept of spirituality, e.g., that definition whereby spirituality concerns the strictly personal relation with the sacred. This epistemological awareness to different concepts implies a distrust of ready-made conceptualizations and leads the researchers to put concepts in parenthesis ${ }^{3}$. Despite the multiple and scattered character of the phenomenon, the grounds provi-

\footnotetext{
${ }^{3}$ The necessity of parenthesizing notions in the social sciences of religion was previously emphasized by Meyer (2014).
} 
ded by empirical and particular situations can help us to understand spirituality beyond those assumptions that have been accompanying our thoughts for more than a century.

\section{NEWS OF THE FIELD}

As I suggested before, the analytical necessity of recognizing the theoretical proximity and distance between New Age and spirituality is important because it enables us to expand horizons and to look for other facets to be found. Usually, alternative/intentional communities were the prior locus of research when the theme was New Age or spirituality (Carozzi, 1999). What my own fieldwork has shown is that ecovillages - taken in the broader sense as "communities for difficult times" (Léger \& Hervieu, 1983) - are places in which the drifts of spirituality and the currents of ecological thought meet.

Before proceeding to the next steps, some words to contextualize the fieldwork realized for 22 days in 2017 and 25 days in 2018, in the ecovillage Arca Verde (Green Arc), situated in São Francisco de Paula, state of Rio Grande do Sul. The ecovillage was founded in 2005. The fieldwork was done to grasp the minutiae of the relations of spirituality and ecology in the ecovillage and included observation of activities, description of organization and interviews.

In the first moment, the ecovillage Arca Verde was situated in an inospite region on the peak of enormous mountains of Atlantic forest, in a place called São José dos Ausentes. Activities, workshops and experiences regarding sustainability were carried out by the people who lived there, and having faced rigorous weather conditions for four years, in 2009 they moved to a small city called São Francisco de Paula, in the region of the pampas of Rio Grande do Sul. Although the cold winters are still present, it is now possible to cultivate native fruit trees and vegetables.

The ecovillage is composed of houses built according to specific architectural techniques ( $\mathrm{COB}$ ), which use clay to sustain the walls, and the results are interesting buildings with glass ceilings covered by plants (called living roof); there is also a dry composting toilet (which does not use water); and a yurt (portable round tent used by ancient people of Central Asia). The number of people who live in the place today varies from 15 to 20 , including children, women and men, all of whom are free to express their own sense of spirituality, without any constraints. Most of them are educated people who were raised within Christian religions, such as Catholicism, and traditional modalities of Protestantism, such 
as Lutheran Church. Nevertheless, their notions of spirituality are associated with the connection with Earth and nature as the sacred space in which the rhythms and cycles of this huge set of organisms and living beings they call "web of life" (Capra, 1996). That is an important expression of what I would like to call immanent sacred of nature 4 .

In the ecovillage, offering communal ceremonies is supported and people cultivate different forms of connection with the sacred, always in relation to nature, including neo-shamanic practices, yoga, meditation, sacred feminine circles and ritualizations of moments in community, like meetings, breakfast and lunches ${ }^{5}$. Before lunches, the chanting of songs that gratefully praise the elements and nourishment is quite common. The spiritual experience is immediate, in the sense that it does not require religious institutions, or spiritual leaders. The relation with Earth is immanent because the connection with the land and its elements can be experienced -- touched, felt, smelled and eaten. The immanent sacred of nature is founded by "an immanent spirituality in which people connect themselves with the sacred through the elements of nature" (Comunello \& Carvalho, 2015, p. 97).

On the other hand, there is another aspect of the concept of immanent sacred of nature that I am presenting and that I will return to in the next session. A woman who is a psychologist and was about 25 years old once told me that for her "spirituality was diluted in everyday life". This idea of a sacredness of life in its mundane forms was shared by other people in the ecovillage. Thus, spirituality is not circumscribed by the rituals in temples because "the spiritual is everywhere, in everything, in every action, in every situation" and "he sacred is in fact everywhere and immanent in every moment of experience." (Holloway, 2003, p. 1972)

Spirituality is included as one of the premises of Permaculture, which is a range of practices and ideas to establish a harmonic mode of living with nature. Permaculture is practiced worldwide and can be considered a philosophy that

\footnotetext{
${ }^{4}$ My understanding of the notion of sacred resonates the concept of Bateson (2006), according to whom the sacred is not an opposition to the profane, and rather can be understood as a scale in which the sacred is on one edge, in the middle the profane, and on the other edge the sacred again. This spectral understanding is valid because it enables us to escape from the dichotomic understanding of sacred and profane as an analogous conceptual construct of religious/profane.

${ }^{5}$ The interesting work of Comunello \& Carvalho (2015) concerns the practices and concepts of the ecovillage Arca Verde as "ecological epistemologies" that entangles and collides the dichotomies of modern thought. The authors refer to some practices as a form of new age spirituality, and I would disagree with that point, once even they noticed that the category "is not used by the dwellers to define their experience of spirituality" (Comunello \& Carvalho, 2015, p. 89). Following accuracy and the coherence of my own argument, I would call all those practices simply "spirituality", and if the analytical specification is needed, "earth based spirituality" (Taylor, 2001).
} 
engenders the "sacralization of nature" as well as the "naturalization of sacred" (Carvalho \& Steil, 2008). One aspect of Permaculture refers to 'Health and Spiritual Well-being', which concerns home birth, complementary and holistic medicine, indigenous cultural revival, dying with dignity and - not less important mind/body/spirit disciplines based on different cultural traditions.

Permaculture as a whole is a complex proposal, which involves a set of principles for an ethics of care; techniques for the cultivation of vegetables and fruits; techniques for architecture and natural construction; premises for the financial management and for a collective government of the community. The three core notions of Permaculture are: Care of people; Care of the Earth; and Return of surplus to Earth and People (or Fair Share). The keywords for those people are cooperation and reciprocity. For them, living in ecovillages concerns political consciousness and ecological commitment with contemporary social problems through an immanent and worldly spiritual path.

Again, the aim of this description is not to draw further considerations of the ethnographic situation of the field, but rather to account for the context from which the following reflections rise. Beyond the fact that people in the ecovillage live in connection with the land, grow their own vegetables, and build their homes using the $\mathrm{COB}$ technique, the most important aspect for us in this reflection regards their sense of spirituality as a search for connection with nature, which is the counterpart of the ecological thought that looks for grasping the pattern that connects living beings. The epistemological and ontological substratum underlying permacultural practices and notions allows an emphasis on the associations between notions of spirituality and ecology subscribed by the people who live there. Furthermore, the contribution of anthropological inductive analysis would suggest that this particular collective may be understood in relation to a broad context, and there is where I want to go with the next section. The notions and experiences in this specific ecovillage could be found somewhere else, and the bibliography about ecological spirituality mentioned in the introduction demonstrates that. Although avoiding hasty generalizations, I would be satisfied to underline that the permacultural notion of spirituality which takes place in ecovillages regards an "earth based spirituality" (Taylor, 2001). 
UNFOLDING THE METHODOLOGICAL TRIANGLE OF SPIRITUALITY, ECOLOGY AND SECULARITY

Concepts regarding secularization have never been completely conclusive among social scientists of religion. Since the nineties, further rational developments of Euro-American societies made the issue more and more intricate, deepening the commonly shared premise: the comprehension that the modern project engendered the reconfiguration between state and religion.

The epistemic category of secular can be understood as a preceding notion in relation to the secularism rooted in the modern mode of life (Asad, 2003). The term secular, a Latin notion appropriated by Christendom, was later used "to structure the entire spatial and temporal reality of medieval Western Christendom into a binary system of classification separating two worlds, the religious-spiritual-sacred world of salvation and the secular-temporal-profane world" (Casanova, 2011 , p. 56). On the other hand, secularism is considered an inherently modern political doctrine concerning a set of principles shared by Euro-American national-states: "constitutionalism, moral autonomy, democracy, human rights, civil equality, industry, consumerism, freedom of the Market - and secularism" (Asad, 2003, p. 13).

The notion of secularism and the narrative of subtraction - according to which the religious exits from the public sphere and where the differentiation of religious and secular results in the privatization of religion and emancipation of state apparatuses from the ecclesial domain - were widely questioned (Casanova, 2011; Calhoun et al., 2011; Taylor, 2007). As the theoretical debates unfolded, the notion of secularism was refined and investigated in various directions, which were multidimensional and by the same token interrelated: in sum, the process of secularization would imply the relative decline of religious belief; the privatization of religion as one counterpart for individual autonomy and the differentiation between the public sphere and religious institutions (cf. Casanova, 1994; Veer, 2009, 2015).

Recent reviews of the debate on the notion of secularism have tried to gather those three directions examined by Taylor (2007) and Casanova (2011), mentioned in the paragraph above and to which authors always return. 
Taylor (2007) suggests another explanation of the thesis of secularization, emphasizing those three meanings once more, and expressing them in another terminology6.

The first (Secularity 1) regards social and political institutions and their formal separation from institutionalized religion - therefore, religion becomes a private matter. The second meaning (Secularity 2) encompasses the decline in the proportion of self-declared believers and decreasing frequency of church attendance. Nevertheless, Taylor is really interested in the third meaning (Secularity 3), which concerns changes in the conditions of belief (Dullo, 2012, p. 381).

Secularity 3 regards the change "from a society in which it is virtually impossible not to believe in God, to one in which Faith, even for staunchest believer, is one human possibility among others". Therefore, "secularity in this sense is a matter of the whole context of understanding in which our moral, spiritual or religious experience takes place" (Taylor 2007, p. 3).

Secularity can be thus considered a phenomenological frame resulting from several historical processes and facts, such as the humanist anthropocentrism; the heliocentric theory of Copernicus; the Enlightenment and its concept of reason; the Protestant Reformation; and the advent of liberalism in a broad sense. Those processes and events together contributed to an ontological and epistemological transformation, liberating the minds from the theological yoke of Catholic institutions on the occasion of the emergence of modern political systems.

There is a polarization in the debate regarding the process of secularization. On one side, there is the postulate of inexorable suppression of religion and, on the other, the postulate of the return of religion as a result of specific appropriations and configurations of secularism. The intention of this article is not to recover infertile antagonisms, but rather to acknowledge the possible articulations between different conceptualizations of the issue of secularism/secularization/secularity. Those articulations are important because the complexities of those phenomena require attention to specific cases.

A specific case is the issue of spirituality and ecology.

The analytical articulation between modernity and spirituality was profoundly elaborated by Veer $(2009,2015)$, whose work has shown that modernity engendered an immanent order in which "the market, the public sphere, and the

\footnotetext{
${ }^{6}$ Sanchis (2001) also suggested a tripartite synthesis of the secularization process. According to $\mathrm{him}$, the process presents three non-exclusive axes, namely the differentiation of social, economic and political instances and the monopoly of the Church; rationalization that would suppress religion; and mundanization, which would cause unexpected alliances between religious institutions and other so called profane aspects of life.
} 
nation-state has transformed the role of institutional religion and in some historical instances (but not in others) marginalized it, but at the same time it has freed a space for spirituality" (Veer, 2015, p. 118). This is a relevant conceptualization because it highlights that the category of spirituality has an intricate relation with the secular modern project.

Veer $(2009,2015)$ has defended the thesis that both the secular and spirituality were produced by Euro-American modernity - they have been raised as alternatives to institutionalized religion. We can understand this assumption if we accept that secularity also refers to changes in the 'conditions of belief' (Taylor, 2007, p. 3). The disjunction of the Church and the state as a signal of modern times was one of the historical forces that gave impulse to the emergence of the category of spirituality, even if this process is not the only factor by which that emergence can be explained. In this sense, secularity has opened different affluents for the flowing concepts of the immanent order of reality:

The great invention of the West was that of an immanent order in Nature, whose working could be systematically understood and explained on its own terms, leaving open the question whether this whole order had a deeper significance, and whether, if it did, we should infer a transcendent Creator beyond it (Taylor, 2007, p. 15).

If modernity is characterized by the detachment of the sacred out of a transcendental system and opens at least the possibility to the sacralization of the immanent whole in which people and nature are inserted, my argument is that spirituality can be considered a search for connection with this immanent whole ${ }^{7}$. On the other hand, there is ecology, which leads to the same search for recognition of the patterns that connect people and nature. What differs here are the terms. Inasmuch as the former concerns a sacralization of nature of a religious kind (in the sense of religare), the later refers to a scientific language, which naturalizes the immanent sacred of nature. Hence, the secular frame in which the immanent order is experienced raises the opportunity for the encounter of spirituality and ecology.

Some ecological approaches, such as deep ecology proposed by the philosopher Arne Naess, tend to lead the environmentalists to a kind of animism, embedded in the notion of the "web of life" (Capra, 1996). In the context of deep

\footnotetext{
${ }^{7}$ My argument also resonates with the conceptualization of Csordas (2004) concerning the spiritual experience as a relation between self and other, which is an understanding recovered from classic theories of religion. In the case of ecological spirituality, the Self is the person and nature is the Other. If Csordas is right about intimate alterity being a fundamental aspect of human existence and religious intersubjectivity, the ideas of connection between humans and nature and of humans as part of nature are also very important to understand the ontology of spiritual ecologists.
} 
ecology, life is understood as an energetic field infused in every being in the Great Chain of Life (Bateson, 1986), including minerals, plants, animals, insects and even worms. The creative force of evolution, as defined by Bergson (2006), is embedded in every being, regardless of their forms. Instead of discontinuity, this ecological thought finds continuity, similarity, cooperation and patterns connecting each being within ecosystems and also connecting ecosystems to the broader systemic web of life. The sense of awe and admiration before nature implies a "sacred perception of environment" (Chiesa, 2017). This experience expressed by a dweller of the ecovillage Arca Verde is a concrete example of the assumptions of deep ecology I have described:

There is another quality of life about living in an ecovillage, feeling the intensity of being in community, and observing all the communities happening here in this place. When you dig the soil up, you see there are many things happening there. It is beautiful to perceive the diversity of plants, the diversity of people. Some plants work like this, some people work like that. You can see the cycles of the plants, and it brings big lessons about life if the person is prone to observe. Earth is Gaia, an enormous living being self regulating its processes. We, as human beings, are one manifestation of the Earth. We are Earth and a manifestation of life on Earth. This is my spirituality. For me, being here with all the Universe here and now is a necessity of experiencing our own perfection (Franco, personal communication, January 17, 2018).

Ecological thought and spirituality imply different forms of perception and search for connection between beings in the lived world. More broadly, ecological thought and spirituality also express the search for connection between analogous parts and wholes, such as organism-system, person-society, mind-nature, individual mind-cosmic consciousness, and so on. We have before us modalities of ecology and spirituality that foster the breakthrough of the conceptual gaps between Euro-American dichotomies. Such premises can be "ecological epistemologies", as Steil \& Carvalho (2014) would call it, because they replace the human among other beings on the level of a symmetric relation of mutual engagement in the lived world. Ecological epistemologies are constantly being expressed discursively by environmentalists who present dialogues with spiritual notions, in different empirical situations (Caravita, 2012; Crespo, 1994; Cykman, 2018). Actually, some authors assert that the sacralization of nature is fundamental to ecological rationality (Giner \& Tábara, 1999).

Both languages of ecology and spirituality are related to secularity, but also appear as counterdiscourses to modernity because ecology and spirituality present, either openly or subtly, a critique of the modern rationalization of the destructive capitalism; the exploitation of Earth to the detriment of future gene- 
rations; the great epistemological divisors; and the fragmentation of working relations, consciousness and life.

The argument resulting from the empirical ground and theoretical analysis is that spirituality and ecology, both understood in the sense of connection between everything that is alive in greater life systems, are manifestations of the ontological immanentization intrinsically related to the secular frame in which Euro-American individuals experience the world. Although the strictly empirical material of this article is circumscribed to a specific set of data regarding my fieldwork, I would suggest that the form of immanentization enacted in the ecovillage Arca Verde is present among other permacultural ecovillages around the globe, because the experiences and knowledge shared by the dwellers of the ecovillage Arca Verde are disseminated throughout networks of ecologists ${ }^{8}$. And, if it is possible to stretch that conclusion, I would also suggest that many ecological communities share those premises, directly and indirectly, for Permaculture and the modality of ecological thought and spirituality it enacts is widespread. If that is the case, the intricate relation of ecological thought and spirituality as different forms of a search for connection between everything that is alive in the world, described and analysed alongside this article, can be even more pervasive than my delimited data allows me to assert. Therefore, the contribution of this article is relevant to understanding the emergent relations between politics, religion, spirituality and environmental issues worldwide in times when ecological crisis is becoming more and more necessary to the public debate.

\section{CONCLUSION: OTHER FACETS TO BE FOUND}

My aim in this article was to present an innovative understanding of spirituality in relation to ecology within the experiential and epistemological realm of the secular era. First, I tried to unravel the knots between the notion of spirituality, New Age and religion. That methodological problematization enables the investigation of spirituality to go beyond the assumptions which have been taken for granted for many years. Then, having presented my anthropological fieldwork as an empirical ground, I drew the overview on the question of secularity, in order

\footnotetext{
${ }^{8}$ The ecovillage Arca Verde, rather than an isolated island of immanent and sacred relation with the land, is also politically connected to many ecovillages alongside two networks. Arca Verde, for instance, is part of GEN (Global Ecovillage Network) and Casa (Consejo de Asentamientos Sustentables de América Latina). On the website of GEN (https://ecovillage.org/), it is possible to find a map with affiliated ecovillages around the world.
} 
to suggest that spirituality is not the only phenomenon imbricated into the secular frame of modernity (Veer, 2009), for the emergence of ecology can also be understood as a phenomenon resulted from the immanentization of experiential reality. I emphasized that the transcendental order of the cosmos is partially replaced by an immanent order in which nature and the Earth, with all living beings always intertwined in ecosystems, are sacralized. I also named this particular phenomenon as immanent sacred of nature.

One possible direction for further investigations would be accounting how spiritual notions are enacted in different empirical situations which goes beyond the individual practices towards the sacred. People and groups who see nature as sacred can no longer be addressed like people and groups only oriented by individual interests, since contemporary environmentalism and even global organizations like Greenpeace are profoundly inspired by spiritual concepts of nature (Taylor, 2001). My attendance at the 2019 Bioneers Conference in San Rafael, California, for example, also revealed that the nonprofit organization Bioneers necessarily includes Indigenous activists and other environmentalists who often account spiritual concepts and language, bringing forth spiritually-oriented political discourses.

Furthermore, spiritual ecologists are not only in ecovillages, but also acting in the political field. This suggests that spirituality is not only a practice of people in their apartments meditating with closed eyes. Those people are inspired by their self-transformation to move themselves in the world towards social action. If the growth of ecology as well as spirituality in Euro-American societies is profoundly related to the secular order characterized by the immanent frame of experience, it can also be true that spirituality is a form of political action within the secular order - which is a possible clue to understand how the secular order has never been only secular. My point raises a set of issues which may be acknowledged for us as social scientists of religion to grasp what has been called the 'post-secular age'. But that is another debate.

\footnotetext{
${ }^{9}$ The debate regarding the post-secular encompasses a range of questions and positions which are somewhat related to the ways through which religion is manifested as social and political force (Meyer, 2006). The post-secularity approach to the study of religion inspired by Asad (2003) concerns the category of the secular as an object of analysis, and particularly the ways the opposition of the secular and the religious are inscribed in "modern social imaginaries" and theoretical frameworks on our study (Meyer, 2006, p. 5). Resonances of this debate can also be found on Steil \& Toniol (2013), Giumbelli \& Toniol (2017), and Reinhardt (2017).
} 


\section{ACKNOWLEDGMENTS}

I would like to thank the organizers of the session "Green Religions and Spiritual Ecologists" at the ISSR/SISR Conference - 2019, Irene Becci, Alexandre Grundjean and Jens Körhsen, with whom I had inspiring dialogues. I also would like to thank Jordan Wainer, who generously helped with a critical reading and the grammar revision. Many thanks to Luis Muñoz Villalon for helping me with the resumen.

\section{REFERENCES}

Amaral, L. (1999). Sincretismo em movimento - O estilo Nova Era de lidar com o sagrado. In M. J. Carozzi (Ed.). A Nova Era no Mercosul (pp. 47-79). Vozes.

Amaral, L. (2000). Carnaval da Alma: Comunidade, essência e sincretismo na Nova Era. Vozes.

Asad, T. (1993). Genealogies of religion: Discipline and reasons of power in christianity and Islam. The Johns Hopkins University Press.

Asad, T. (2003). Formations of the secular: Christianity, Islam, modernity. Stanford University Press. https://doi.org/10.1515/9780804783095

Barnes, L. L. (1998). The psychologizing of Chinese healing practices in the United States. Culture, Medicine and Psychiatry, 22(4), 413-443. https://doi.org/10.1023/A:1005403825213

Bateson, G. (1986). Mente e natureza: uma unidade necessária. Francisco Alves.

Bateson, G. (2006). Una unidad sagrada: pasos ulteriores hacia una ecología de la mente. Gedisa.

Becci, I., \& Grandjean, A. (2018). Tracing the absence of a feminist agenda in gendered spiritual ecology: ethnographies in French-speaking Switzerland. Antropologia, 5(1), 23-38.

Bender, C., \& McRoberts, O. (2012). Mapping a field: Why and how to study spirituality. SSRC Working Papers. https://tif.ssrc.org/wp-content/uploads/2010/05/Why-and-How-toStudy-Spirtuality.pdf

Bergson, H. (2006). A Energia Criadora. Martins Fontes.

Calhoun, C., Juergensmeyer, M., \& Van Antwerpen, J. (2011). Introduction. In C. Calhoun, M. Juergensmeyer \& J. Van Antwerpen (Eds.), Rethinking secularism (pp. 1-30). Oxford University Press.

Camurça, M. (2003). Espaços de hibridização, dessubstancialização e ideias fora do lugar. Ciencias Sociales y Religión, (5), 37-56. https://doi.org/10.22456/1982-2650.2254

Camurça, M. (2016). Estilos de espiritualidade como critério para tipologias e interpretações do campo religiosos na contemporaneidade. Ciências Sociais e Religião, (24), 18-32. https://doi.org/10.22456/1982-2650.58781

Capra, F. (1996). The web of life: A new synthesis of mind and matter. HarperCollins.

Caravita, R. (2012). “Somos todos um”: Vida e imanência no movimento comunitário alternativo [Master's thesis, State University of Campinas]. Repositório da Produção Científica e Intelectual da Unicamp. http://repositorio.unicamp.br/jspui/handle/REPOSIP/279335 
Carozzi, M. J. (1999). Nova Era: A Autonomia como Religião. In M. Carozzi (Ed.), A Nova Era no Mercosul (pp. 47-80). Vozes.

Carvalho, J. J. (1992). Encontros de velhas e novas tradições: esboço de uma teoria dos estilos de espiritualidade. Série Antropologia, (131), 1-21.

Carvalho, I. C. D. M., \& Steil, C. (2008). A sacralização da natureza e a 'naturalização' do sagrado: aportes teóricos para a compreensão dos entrecruzamentos entre saúde, ecologia e espiritualidade. Ambiente \& Sociedade, 11(2), 289-305. https://doi.org/10.1590/S1414753X2008000200006

Casanova, J. (1994). Public Religions in the Modern World. The University of Chicago Press. https://doi.org/10.7208/chicago/9780226190204.001.0001

Casanova, J. (2011). The Secular, Secularization, Secularisms. In C. Calhoun, M. Juergensmeyer, \& J. Van Antwerpen (Eds.), Rethinking Secularism (pp. 54-74). Oxford University Press.

Champion, F. (1993). La Croyance en l'Alliance de la science et de la religion dans les nouveaux courants mystiques et ésotériques. Archives de Sciences Sociales des Religions, (82), 205-222. https://doi.org/10.3406/assr.1993.1649

Chiesa, G. R. (2017). À procura da vida: pensando com Gregory Bateson e Tim Ingold a respeito de uma percepção sagrada do ambiente. Revista de Antropologia, 60(2), 410-435. https://doi.org/10.11606/2179-0892.ra.2017.137315

Comunello, L. N., \& Carvalho, I. C. D. M. (2015). Ecovilas: aprendizagens, espiritualidade e ecologia. Avá. Revista de Antropología, (27), 81-99.

Crespo, S. (1994). Sincretismo ou ecletismo religioso? Notas para um estudo sobre a espiritualidade ecologista. Comunicações do ISER, (45), 75-87.

Csordas, T. (2004). Asymptote of the ineffable: embodiment, alterity, and the theory of religion. Current anthropology, 45(2), 163-185. https://doi.org/10.1086/381046

Cykman, N. (2018). Limites do horizontes: cartografia de uma episteme utópica em encontros Rainbow [Master's thesis, State University of.Santa Catarina]. Repositório Institucional da UFSC. https://repositorio.ufsc.br/bitstream/handle/123456789/199007/PSOP0650-D.pdf

D'Andrea, A. A. F. (2000). O self perfeito e a nova era: individualismo e reflexividade em religiões pós-tradicionais. Loyola.

Dullo, E. (2012). Artigo bibliográfico após a (antropologia/sociologia da) religião, o secularismo? Mana, 18(2), 379-392. https://doi.org/10.1590/S0104-93132012000200006

Giner, S., \& Tábara, D. (1999). Cosmic piety and ecological rationality. International Sociology, 14(1), 59-82. https://doi.org/10.1177/0268580999014001004

Giumbelli, E., \& Toniol, R. (2017). What is spirituality for? New relations between religion, health and public space. In R. Blanes, J. Mapril, E. Giumbelli, \& E. Wilson (Eds.), Secularisms in a Postsecular Age? Religiosities and Subjectivities in Comparative Perspective (pp. 147-216). Palgrave Mcmillan. https://doi.org/10.1007/978-3-319-43726-2_7

Guerriero, S., Stern, F. L., \& Bessa M. Q. (2016). A difusão do ethos Nova Era e o declínio de seus estudos acadêmicos no Brasil. Rever, (16), 9-39. https://doi.org/10.21724/rever.v16i3.31180

Hanegraaff, W. J. (1996). New age religion and western culture: Esotericism in the mirror of secular thought. Brill. https://doi.org/10.1163/9789004378933 
Hanegraaff, W. J. (1999). New Age Spiritualities as Secular Religion: a Historian's Perspective. Social Compass, 46(2), 145-160. https://doi.org/10.1177/003776899046002004

Heelas, P. (2006). Challenging Secularization Theory: The Growth of "New Age" Spiritualities of Life. The Hedgehog Review, 8(1-2), 46-58.

Holloway, J. (2003). Make-believe: spiritual practice, embodiment, and sacred space. Environment and Planning A, 35(11), 1961-1974. https://doi.org/10.1068/a3586

Koehrsen, J. (2018). Eco-Spirituality in Environmental Action: Studying Dark Green Religion in the German Energy Transition. Journal for the Study of Religion, Nature \& Culture, 12(1), 34-54. https://doi.org/10.1558/jsrnc.33915

Léger, D., \& Hervieu, B. (1983). Des communautés pour les temps difficiles. Cerf.

Luiz, R. R. (2013). A religiosidade dos sem religião. Ciências Sociais e Religião,15(19), 73-88. https://doi.org/10.22456/1982-2650.44576

Magnani, J. G. C. (1999). Mystica Urbe: um estudo antropológico sobre o circuito neo-esotérico na metrópole. Studio Nobel.

Magnani, J. G. C. (2000). O Brasil da Nova Era. Jorge Zahar.

Meyer, B. (2006). Religious sensations: Why media, aesthetics and power matter in the study of contemporary religion. Vrije Universiteit.

Meyer, B. (2014). Mediation and the genesis of presence: toward a material approach to religion. Religion and Society: Advances in Research, (5), 205-230.

Oliveira, A. (2014). Nova Era com Axé: umbanda esotérica e esoterismo umbandista no Brasil. Revista Pós Ciências Sociais, 11(21), 167-183.

Reinhardt, B. (2017). Temporalidade, ética e contingência na pós-colônia africana: esperando por Deus em Gana. Ilha Revista de Antropologia, 19(2), 175-212. https://doi.org/10.5007/2175-8034.2017v19n2p175

Sanchis, P. (2001). Desencanto e formas contemporâneas do religioso. Ciencias Sociales y Religión, (3), 27-44. https://doi.org/10.22456/1982-2650.2168

Santos, R. W. (2017). A salvação agora é verde: Ambientalismo e sua apropriação religiosa pela Igreja Católica. Universidade de São Paulo.

Steil, C. A., \& Carvalho, I. C. D. M. (2014). Epistemologias ecológicas: delimitando um conceito. Mana, 20(1), pp. 163-183. https://doi.org/10.1590/S0104-93132014000100006

Steil, C. A., \& Toniol, R. (2013). A crise do conceito de religião e sua incidência sobre a antropologia. In E. Giumbelli, V. Gimenéz Béliveau (Eds.), Religión, cultura y política en las sociedades del siglo XXI (pp. 137-158). Biblos.

Taylor, B. (2001). Earth and Nature-Based Spirituality (part 1): From Deep Ecology to Radical Environmentalism. Religion, (31), 175-193. https://doi.org/10.1006/reli.2000.0256

Taylor, C. (2007). A secular age. Harvard University Press. https://doi.org/10.2307/j.ctvxrpz54

Toniol, R. (2015a). Do espirito na saúde: Oferta e uso de terapias alternativas/complementares nos serviços de saúde pública no Brasil. [Doctoral dissertation, Federal University of Rio Grande do Sul]. Lume - Repositório Digital da UFRGS. https://www.lume.ufrgs.br/bitstream/handle/10183/134201/000985756.pdf 
Toniol, R. (2015b). Leaving the New Age. In H. Gooren (Ed.), Encyclopedia of Latin American Religions. https://doi.org/10.1007/978-3-319-08956-0_22-1

Torre, R. (2011). Les rendez-vous manqués de l'anthropologie et du chamanisme. Archives de Sciences Sociales des Religions, (153), 145-158. https://doi.org/10.4000/assr.22798

Veer, P. (2009). Spirituality in modern society. Social Research, 76(4), 1097-1120.

Veer, P. (2015). Introduction to the Modern Spirit of Asia. Cultural Diversity in China, 1(2), 115-140.

Viotti, N. (2018). La espiritualidad en América Latina. In J. Esquivel, \& V. G. Béliveau (Eds.), Religiones en cuestión: campos, fronteras y perspectivas (pp. 233-236). Fundación CICCUS. 